ISSN 1816-6075 (Print), 1818-0523 (Online)

Journal of System and Management Sciences

Vol. 10 (2020) No. 1, pp. 121-138

DOI: $10.33168 / J S M S .2020 .0109$

\title{
Multiparty Negotiation: Conceptual Approach of Method Selection
}

\author{
Andrzej Kozina ${ }^{1}$, Marek Szarucki ${ }^{2}$, Jurgita Raudeliūniené ${ }^{3}$ \\ ${ }^{1,2}$ Cracow University of Economics, Rakowicka 27, 31-510 Kraków, Poland \\ ${ }^{3}$ Department of Business Technologies and Entrepreneurship, Faculty of Business \\ Management, Vilnius Gediminas Technical University, Saulètekio al.11, 10223, \\ Vilnius, Lithuania \\ Emails: ${ }^{1}$ kozinaa@uek.krakow.pl, ${ }^{2}$ szaruckm@uek.krakow.pl, ${ }^{3}$ jurgita.raudeliuniene@vgtu.lt
}

\begin{abstract}
Globalization, technological progress and transformation processes ranging from information to knowledge society affect not only organizations' structural management changes and behavioural patterns but also play an important part of business areas such as multiparty negotiations. Scientists and business practitioners underline that multiparty negotiation is one of the most dynamic and critical elements in a business exchange which leads to business leadership and is a research area that has need of further conceptual and empirical development. This study aims to develop an original conceptual framework of selecting methods for solving the crucial research problem of multiparty negotiations in order to facilitate the negotiation process and succeed. To reach the aim of the study a scientific literature review and G. Nadler's ideal system concept were applied as a basis for developing a multiparty negotiation conceptual framework of method selection.
\end{abstract}

Keywords: Business negotiation, multiparty negotiation, conceptual framework, method selection.

\section{Introduction}

Within a global business environment, numerous, dynamic and complicated inter and intra organizational relations of both a competitive and cooperative nature result in the sharply increasing scope and importance of business negotiations (Greenhalgh et al. 1985; Alder et al. 1988; Tinsley et al. 1999; Watkins 2002; Esqueda 2012; Caputo 2013; Kozina 2014; Grabowska \& Kozina 2016; Agndal et al. 2017; Kern et al. 2020). When there is a noticeable growth of business 
negotiations that involve more than two parties it becomes increasingly more difficult to reach a satisfactory agreement between numerous stakeholders (Klenk et al. 2012; Sarabando et al. 2013; Zhou et al. 2014; Sagi \& Diermeier 2017; Caputo, 2019; Lee et al. 2019). This type of negotiation occurs during the establishment of strategic partnerships, while undertaking joint ventures, forming strategic alliances, performing mergers and acquisitions, creating networks and virtual organizations, maintaining industrial relations and within other complex transactions that comprise numerous issues and parties, as well as those involving considerable risk (Greenhalgh 2001; Inkpen \& Ross 2001; Franco 2008; Crump 2015; Jang et al. 2018). The most important factors that enhance the prominence of multiparty negotiation are technological development and a substantial broadening of knowledge in many domains of activities, as well as changes in management systems within contemporary organizations (mainly decentralization of decisionmaking) and the social manner of human nature (Heiskanen 1999; Kamiński 2003; Lee \& Kwon 2006). Therefore, it is necessary to search for complex methodological tools for analyzing and conducting multiparty negotiations which would facilitate resolving practical problems that occur in such negotiations.

However, it may be observed that despite the key role played by the issue of multiparty negotiation, so far, there is lack of a complex and coherent methodological concept of such negotiations that has been elaborated and which is a research area that needs further conceptual and empirical development (Dupont 1994; Zartman 1994; Watkins 2002; Crump 2003; Crump \& Glendon 2003; Susskind \& Crump 2008; Agndal et al. 2017). To find a conceptual solution to the identified gap in the research area of multiparty business negotiation, this study aims to develop an original conceptual framework of selecting methods for solving the crucial research problem of multiparty negotiations in order to facilitate the negotiation process and succeed. To reach the aim of the study a scientific literature review and G. Nadler's ideal system concept were applied as a basis for developing a multiparty negotiation conceptual framework of method selection.

\section{The Features of Multiparty Negotiation}

Multiparty negotiation can be defined similarly to the two-party (bilateral or dyadic) of negotiation (Crump 2015). Generally, multiparty negotiation is treated as a process, i.e. a complex venture (project) which includes various activities of the parties interested in reaching an agreement and resolving conflicts that may occur (Kaufman et al. 2018). These activities interact with one another in many different ways. Such a process can be characterized by several aspects that reflect different features of business multiparty negotiations. First of all, such negotiations constitute an interactive decision making process. At the initial stage of the process the varying parties formulate their own alternative solutions to the considered problems and specify criteria for the evaluation of those alternatives, which solely reflect the 
individual parties' goals and interests. Next, all negotiators must adjust both their alternatives and criteria in order to reach common ground at a level satisfactory to all parties. The decisional aspect of negotiations is the most important for the purpose of their analysis, planning, organizing and conducting. The other essential aspects of business negotiations are as follows (Kamiński 2003; van Beest et al. 2008; Olekalns \& Smith 2009; Lewicki et al., 2010; Caputo 2013; Thompson 2016): conflict resolution and search for an agreement, mutual dependence between parties, the interpersonal communication process, mutual exchange of values (tangible and intangible), and creation of new values (material and intangible).

On the other hand, when it is necessary to simultaneously negotiate with more than one partner (usually on numerous issues), the negotiation situation differs substantially from typical two-party negotiations. This is due to both the number of parties and relations between them which results in the complexity of such negotiations, including all above mentioned processes that characterize negotiations in general, and the decision making process in particular. According to L. Crump and A. I. Glendon (2003, p. 197), "negotiations involving multiple parties are complex because of the potential number of interacting variables. Understanding multiparty negotiation is hindered by a lack of theory that can adequately explain the multiplicity of interactions that typically characterize such negotiations. Negotiation sides, parties and roles are just some of the many variables that interact to produce outcomes. The complexity generated through such interaction is a challenge for theory development”. R. E. Kramer (1991) defines multiparty negotiation as a group of three or more individuals, each representing their own interests, who attempt to resolve perceived differences of interest. Multiparty negotiations are perceived as more complicated than two-party or dyadic negotiations, especially when considered from the perspective of the fixed pie perceptions that are the "negotiators' beliefs that the counterparty's interests and priorities are in direct opposition to the negotiator's own interests and priorities" (Kern et al. 2020, p. 143). This intricacy encourages the expectation that one party will have some interests analogous to his/her own interests and this disturbs the fixed pie perception. Moreover, this complexity similarly stimulates a diverse use of strategies to achieve agreements as efficiently as those of two-party negotiators. Major features of multiparty negotiations compared to the attributes of bilateral negotiations are presented in Table.1. 
Table.1: Comparison between two-party and multiparty negotiations (adapted by

Kamiński 2003)

\begin{tabular}{|c|c|c|}
\hline Factor & Two-party negotiations & Multiparty negotiations \\
\hline Mutual dependences & $\begin{array}{l}\text { Unequivocal, homogeneous, simple and } \\
\text { relatively easy to identify and analyze }\end{array}$ & $\begin{array}{l}\text { Equivocal, heterogeneous, complicated, } \\
\text { difficult to identify and analyze }\end{array}$ \\
\hline $\begin{array}{l}\text { Conditions of potential } \\
\text { agreement }\end{array}$ & $\begin{array}{l}\text { Reciprocal acceptance of both parties is } \\
\text { required (while making decisions) }\end{array}$ & $\begin{array}{l}\text { The acceptance of all parties is not } \\
\text { always necessary and/or possible }\end{array}$ \\
\hline Negotiators' behavior & Mutual reactions to one's behavior & $\begin{array}{l}\text { Negotiators' behavior is placed within } \\
\text { too much broader and multidimensional } \\
\text { context }\end{array}$ \\
\hline Nature of process & $\begin{array}{l}\text { Communication, exchange and value } \\
\text { creation processes within bilateral } \\
\text { relations }\end{array}$ & High complexity of these processes \\
\hline Negotiation strategies & $\begin{array}{l}\text { Two basic strategies: cooperative and } \\
\text { competitive ones (different combinations } \\
\text { are possible) }\end{array}$ & $\begin{array}{l}\text { Greater number of potential strategies } \\
\text { of the parties }\end{array}$ \\
\hline
\end{tabular}

For many multiparty negotiators it is not obvious what kind of participants should be considered, i.e. how to define the negotiating parties. Therefore, a wide methodological framework of multiparty negotiation analysis comprises the following aspects of so called "building blocks" (Crump \& Glendon 2003): (1) primary party relations (primary parties engaged in a negotiation), (2) cooperative relations between parties on the same side (coalitional relations), (3) noncooperative relations inside a "single party" (that is not behaving as a unitary entity), (4) third party relations (arbiters, mediators, or moderators), and (5) entities providing support to a primary party (agents, experts, or advisors).

As a useful methodological framework to thoroughly describe multiparty negotiations, R. M. Kramer's (1991) concept can be applied. Kramer's concept considers the following dimensions of complexity of such negotiations: informational (includes the computational dimension, originally considered separately), social, procedural and strategic.

Informational - results from the appearance of a considerable amount of differential data describing the negotiation situation (parties' goals and interests, negotiations' scope, resources, tools, context, etc.) and desirable to be included in its analysis. Both objective and subjective difficulties in gathering necessary information and evaluating its effectiveness occur as well as the threat of data redundancy appears. Such complexity is accompanied by computational difficulties which are caused by substantial obstacles and limitations to the activities of processing, interpreting, verifying, and analyzing information to identify and shape particular negotiation situations. Additionally, those processes are usually highly complicated and cost intensive.

Social - reflects both psychological (individual) and sociological (group) aspects of human behaviors in negotiations. Potential problems are caused by the large number and diversity of goals, needs, ideas, expectations, attitudes and personalities of negotiating parties, as well as the various interactions between them. Either individual behaviors or group processes may substantially restrict the rationality of 
activities within negotiations. These are groupthink syndrome, group polarization or risky shift phenomena. Analysis of social complexity of multiparty negotiations seems to be the most difficult issue.

Procedural - it is necessary to identify and solve numerous problems regarding the organization of a negotiation process. These are issues concerning elaboration and implementation of proper procedures and rules referring to the participants of the negotiations, their agenda and schedule, sequence and time of presentations, manner of leading discussions and disputes, place and territory, and so on.

Strategic - this dimension appears to be the most important (converges the other dimensions). It results from objective difficulties with classification and selection of multiparty negotiations strategy, as well as specific tools (offers, arguments, techniques) that concretize such strategy. The strategic dimension also comprises the decision making processes, especially agreeing on the alternatives, adjusting common criteria and finding a decision making rule for choosing the best solutions (Kozina 2012).

The above described dimensions of the complexity of multiparty negotiations allow to identify the key research problems in the discussed research field.

\section{Negotiation as a Managerial Problem and Method- Selecting for Its Solution}

Negotiations as a management problem. Organizations experience a growing number of different problems, among which managerial problems play an important role and influence the organization's leadership position (Szarucki, 2015). Managerial or management problems are related to the discrepancy noticed by a manager in comparison to what is perceived and the desired result (Szarucki, 2013). The problem must be both perceived and resolved by a manager irrespective of her/his position in the organizational hierarchy.

Management problems are analyzed and discussed from different perspectives: organizational (e.g. human resources, logistics, marketing, financial, production), level of organizational hierarchy (e.g. strategic, tactical, operational), time perspective (e.g. long run, short run) and methodological (e.g. application of methods for problem-solving). Studies have attempted to present different dimensions and classification frameworks to support better understanding of the relationships and features of managerial problems (Maier \& Hoffman, 1964; Simon 1973; Nadler, 1983; Smith, 1988; Walsh, 1988; Cowan 1991; Szarucki 2010, 2015).

Typically, managerial problems are related to organizations and their activity, in spite of the fact that management itself may be present in the absence of formal organization (e.g. management of personal funds) meaning that some managerial actions such as planning may occur. Negotiations as a management problem can be perceived as internal (inside) or external (outside) to an organization or including 
both internal and external, i.e. mixed (Figure 1), where Pi is specific negotiations as a managerial problem, pi is first level of attributes of the problem $\mathrm{Pi}$, and pi' is second level of attributes characterizing the problem Pi. Depending on the level of analysis and research objectives there can be added additional levels of problem attributes.

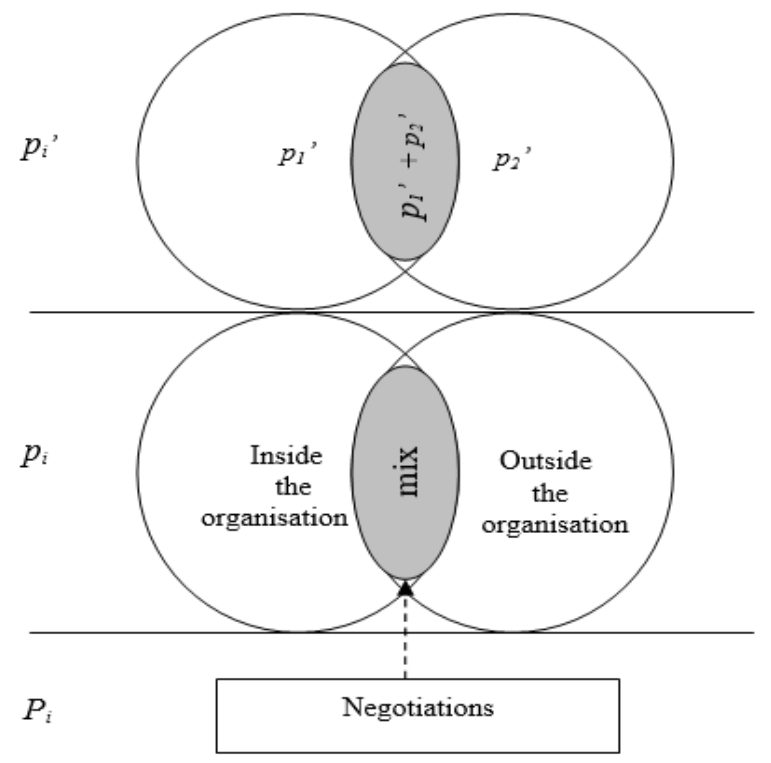

Fig. 1: Negotiation as a management problem and its attributes (created by the authors)

Some other possible classification criteria for problem attributes are the source initiating the problem, causal character of the problem, conditions under which the problem is solved, possibility to express the problem in numbers (to quantify), decision options, level of individual involvement within problem solving, management functions to which the problem could be related, problem complexity and the organizational level. These attributes are of a general nature and applicable to negotiations as a part of the management problems research area.

Negotiations are a matter of fact when solving specific managerial problems and may also be perceived as management problems. Usually they occur when the strategic problems of an organization are being solved (e.g. such as a future merger or acquisition) as well as when human resources management problems arise (e.g. a group of employees must be laid off). Often, these negotiations are multiparty. From the managerial point of view, multiparty negotiations may be perceived in a twofold manner: as a managerial problem in itself, and as a method for management problem-solving. According to the goal of this research, multiparty negotiations will be explored from both perspectives, as a management problem itself as well as a tool for problem-solving. Thus, it is crucial to find an answer to the question: How 
to select an appropriate method to solve the considered managerial problem from each of the mentioned perspectives? Further on, a conceptual framework for method selection in the process of managerial problem-solving, providing some methodological guidance for solving the multiparty negotiations' problems will be presented.

Methodological issues related to method selection and its application to solve problems are of importance to managers as decision-makers. This task becomes difficult to perform due to many reasons that limit one's ability to choose an efficient tool. Among others, it is worth mentioning such reasons as (Gift \& Kinney 1996; Potocan et al. 2012) the huge number and variety of methods of problemsolving, lack of knowledge regarding methods and skills of their utilization, lack of resources necessary for method implementation. Here we focus on the methodology of selection of methods since complex research results on this topic are scarce in the management field. This scientific matter needs to be attended to by management science scholars in order to improve organizations' functioning and development.

Scientific studies on taxonomy of management methods and principles of their selection for problem solving in organizations are limited. Some of these methodological findings seem to be suitable to apply when choosing methods for management problem-solving (Gift \& Kinney 1996; Hagemeyer et al. 2006; Holland \& Dawson 2011; Jun et al. 2011; Potocan et al. 2012). For example, in their study, Gift and Kinney (1996) stressed the importance of three key considerations for selection of a suitable management method for a specific situation: the organizational context, the specific method's attributes, and the selected features of the content area. On the other hand, Jun et al. (2011) have suggested to use a modeling and simulation method comparison and selection tool to support choosing methods suitable to aiding specific decision-making operations based on research in the health services management area. An interesting study was conducted by Hagemeyer et al. (2006), in which researchers investigated quality tools and proposed a useful classification scheme allowing the problem-solver to identify the correct method applied at the right time in the process of problem-solving. A similar study on selection of method classification and methodology in the area of knowledge management was conducted by Holland and Dawson (2011). According to Potocan et al. (2012), selecting an appropriate method for management problemsolving requires taking into account the attributes of the known methods, their comparison and analyzing the demands and conditions of the organizations.

Based on the scientific literature review presented above, several conclusions could be formulated in the context of multiparty negotiation as a management problem. First, there are many different management problems faced by organizations and many methods of solving them related to negotiations. This state of affairs leads to some methodological difficulties associated with selection of an appropriate method for problem-solving while performing multiparty negotiations. 
Second, there is a lack of a unified approach in the analyzed research area that would be proper for problem solving in diverse organizational settings. Additionally, the complex methodology of method selection identified in the research area is limited. Moreover, it is problem-specific (e.g. knowledge management problems or quality problems) that make it confusing (sometimes impossible) to apply in organizations operating under different conditions and in other business areas. Consequently, there is a need for developing a universal methodological concept of method selection for management problem solving which will help direct decisionmakers towards better means of solving the problem of multiparty negotiation.

Concept of method selection for managerial problem-solving. Based on the analysis of the theoretical concepts related to method selection for problem solving it is possible to point out some rational directives that will enhance the process of method selection. Developing a universal conceptual framework of method selection for managerial problem solving is of value for two reasons. Firstly, it furthers building the management science theory and makes a significant contribution to the development of its methodology. Secondly, it provides a conceptual framework which can simultaneously be adopted to different organizational contexts thereby improving the process of management problem solving.

The proposed conceptual framework of method selection in the process of managerial problem-solving is based on the approach and key assumptions of the concept of the ideal system introduced by G. Nadler that is known as IDEALS (Ideal Design of Effective and Logical Systems) Concept (Nadler 1967). According to his approach, the ideal system stands for the perfect, the best and flawless, "prime" system that reaches the ideal that is attempted to be achieved. Nadler (1981) identified three levels of the development of the ideal systems: the theoretical ideal system, the ultimate ideal system, and the technologically workable ideal system. In this subsection we present the theoretical assumptions behind the feasible ideal system, which is a "workable, technologically feasible and doable system that may have several alternative representations from which we select the most desirable and obtainable" (Banathy 1996, p. 191). The graphical presentation of the conceptual framework of method selection in the process of problem-solving of multiparty negotiation is presented below (Figure 2). 


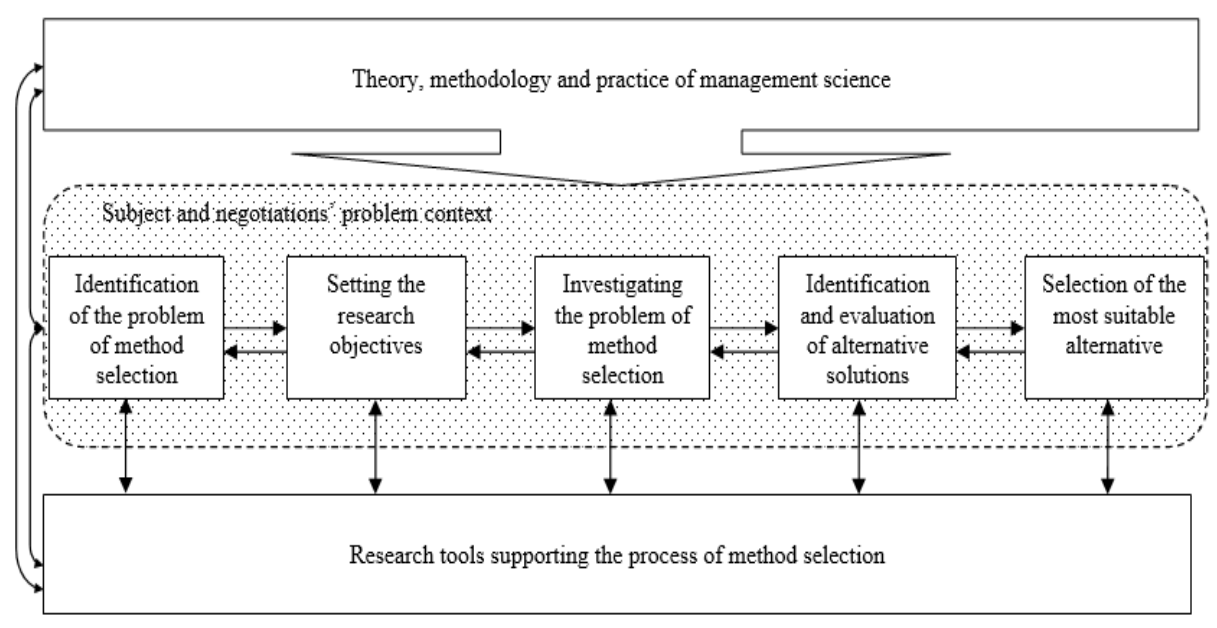

Fig. 2: Conceptual framework of method selection for multiparty negotiation's problemsolving (created by the authors)

The proposed conceptual framework consists of three main areas: (1) theory, methodology and practice of management science, (2) subject and negotiations' problem context, and (3) the research tool supporting the process of method selection.

The first mentioned area is composed of various theories and methodologies developed in the process of management science evolution (Holt 1987; Roth 1994; Mingers \& Gill 1997; Scandura \& Williams 2000; Wren \& Bedeian 2009; Lisiński 2013), as well as different practices of solving management problems related to multiparty negotiation. The elements constituting this area provide the subject dealing with the process of problem-solving of specific theoretical and methodological background supporting the individual's (or team's) efforts.

The second area relates to the subject (person or team) involved in the process of problem-solving and specific context of the negotiations' problem being solved (Figure 2). This area describes the main elements of the process of method selection for negotiations' problem-solving and includes the following research phases: (1) identification of the problem of method selection, (2) setting the research objectives, (3) investigating the problem of method selection, (4) identification and evaluation of alternative solutions, and (5) selection of the most suitable alternative. The sequence of the interrelated phases consequently leads from the identification of the method selection problem to the last phase where the method is selected. Individual characteristics and skills of the subject and the specifics of the negotiations' problem being solved have a crucial impact on the process of method selection.

The third area stands for the toolbox of instruments supporting the method selection process present in the aforementioned area (Figure 2). Each phase of the process of method selection needs specific tools to perform its main tasks, that is 
tools supporting the process of method selection of negotiations problem-solving. Choice of tools for each phase will depend on the theoretical-methodological approach applied from the first area as well as on the skills of the subject (individual or team) involved in the process of problem-solving. The context of the managerial problem is also of importance (i.e. context of multiparty negotiations). Thus, all three areas of the presented universal concept of method selection are interrelated and have a plausible impact on the final result of the research process.

\section{Selection of Methods for Solving Problems in Multiparty Negotiation and Discussion}

Multiparty negotiation can be perceived as a management problem itself as well as a method to solve other managerial problems. The main research problem is to search for such theoretical concepts that could reflect the features of multiparty negotiation, in particular their complexity, by creating both their thorough description and comprehensive tools needed for conducting them. Therefore, the main aim is to create a complex (multidimensional) framework of multiparty negotiation that will require the accomplishment of two partial objectives - the identification of such negotiations and creating the tools for conducting them. As the result of achieving these two objectives, the suggested conceptual framework of multiparty negotiation will comprise two components reflecting general research problems: (1) descriptive - the specification of the features of such negotiations, their determinants (conditions), as well as interactions among them - focused on answering the question "what is multiparty negotiation and what factors influence them?", and (2) normative - the set of tools ("toolbox"), i.e. particular models, principles (rules), recommendations, methods and techniques and so forth, determining the way of conducting the negotiations - aimed at answering the question "how should multiparty negotiation be performed?".

It is assumed that specific, detailed research problems may be distinguished considering those two components and refining them according to the dimensions of the complexity of the multiparty negotiation described in the second part of the article. The methods of solving these problems may be determined by using the conceptual framework proposed in the third part of the article (Table.2 and Table.3).

As can be noticed from Table 2, in order to solve the descriptive problems, they are grouped into four dimensions of complexity. Each dimension deals with specific kinds of problems that can be described in a more or less detailed manner, according to the identified problem attributes (Figure 1). 
Table 2: Descriptive problems and methods of multiparty negotiation research

\begin{tabular}{|c|c|c|}
\hline $\begin{array}{l}\text { Dimensions } \\
\text { of complexity }\end{array}$ & Problems to be solved & The groups of methods of solving problems \\
\hline Informational & $\begin{array}{l}\text { Identifying, classifying and } \\
\text { gathering the data reflecting } \\
\text { crucial features of negotiations } \\
\text { and factors influencing them as } \\
\text { well as presenting such data in the } \\
\text { form of parameters (measures and } \\
\text { indicators). }\end{array}$ & $\begin{array}{l}\text { 1. Techniques of negotiations data identification } \\
\text { 2. Methods of negotiations data collection and } \\
\text { interpretation } \\
\text { 3. Techniques of negotiations data ordering and } \\
\text { classification } \\
\text { 4. Methods of negotiations data processing and } \\
\text { operationalization } \\
\text { 5. Techniques of negotiations data presentation } \\
\text { and interpretation } \\
\text { 6. Models and methods of managing } \\
\text { 7nformation } \\
\text { 7. Techniques of analysis (legal, economic, } \\
\text { 8. Stancial, organizational, technical etc.) } \\
\text { regression analysis, taxonomic techniques, } \\
\text { trends analysis, etc. } \\
\text { 9. Systems analysis }\end{array}$ \\
\hline Social & $\begin{array}{l}\text { Clarifying the nature and typical } \\
\text { mechanisms of negotiators' } \\
\text { individual and group behaviors } \\
\text { and relations between them as } \\
\text { well as explaining the reasons for } \\
\text { that behaviors and their } \\
\text { consequences. }\end{array}$ & $\begin{array}{l}\text { 1. Methods of studying and explaining } \\
\text { individual perceptions and behavior } \\
\text { 2. Techniques of studying and explaining group } \\
\text { perceptions and behavior } \\
\text { 3. Methods of studying interpersonal } \\
\text { interactions and intra and inter group } \\
\text { relations } \\
\text { 4. Methods of analyzing intra group relations - } \\
\text { sociographs, network analysis etc. } \\
\text { 5. Psychological methods - self-assessment test, } \\
\text { interviews, questionnaires, etc. } \\
\text { 6. Sociological methods - action research, } \\
\text { group role models and analysis, etc. } \\
\text { 7. Experts' methods }\end{array}$ \\
\hline Procedural & $\begin{array}{l}\text { Indicating and characterizing } \\
\text { environmental determinants of } \\
\text { negotiations organization, such as } \\
\text { time, place, space arrangement, } \\
\text { availability of resources, facilities, } \\
\text { equipment, etc. }\end{array}$ & $\begin{array}{l}\text { 1. Methods of environmental determinants } \\
\text { identification } \\
\text { 2. Methods of environmental determinants } \\
\text { analysis } \\
\text { 3. Methods of environmental determinants } \\
\text { evaluation } \\
\text { 4. Experts' methods } \\
\text { 5. Process diagrams and maps } \\
\text { 6. Statistical methods - correlation and } \\
\text { regression analysis, taxonomic techniques, } \\
\text { etc. }\end{array}$ \\
\hline Strategic & $\begin{array}{l}\text { Recognizing and exploring the } \\
\text { most important circumstances } \\
\text { (opportunities and threats) to } \\
\text { decision processes and } \\
\text { negotiation strategies and the } \\
\text { extent of potential impact of those } \\
\text { circumstances on negotiations } \\
\text { process and outcomes. }\end{array}$ & $\begin{array}{l}\text { 1. Heuristic methods } \\
\text { 2. Experts' methods } \\
\text { 3. Techniques of strategic analysis (PEST, } \\
\text { SWOT, scenario method, stakeholder's } \\
\text { analysis, etc.) } \\
\text { 4. Systems analysis } \\
\text { 5. Techniques of analysis (legal, economic, } \\
\text { financial, organizational, technical, etc.) }\end{array}$ \\
\hline
\end{tabular}

Based on the results of analysis of the problem's characteristics, the intended goal to achieve has to be determined. Achieving the goal is therefore equivalent to the problem being solved. Thus, the methods to solve the problem must be selected. Using the conceptual framework of method selection (Figure 2), the tools to solve problems belonging to specific categories are grouped together. As a result, for multiparty negotiation' problems within the informational dimension, nine groups of methods were identified. Problems perceived as social can be solved with seven 
groups of methods, those procedural and strategic - six and five groups respectively. A decision maker can continue the process of method selection by using the appropriate criteria and limitations. A similar set of actions included in the concept of method selection for managerial problem solving is then applied to solve the normative problems of multiparty negotiations (Table.3).

Table 3: Normative problems and methods of multiparty negotiation research

\begin{tabular}{|c|c|c|}
\hline $\begin{array}{l}\text { Dimensions } \\
\text { of complexity }\end{array}$ & Problems to be solved & The groups of methods of solving problems \\
\hline Informational & $\begin{array}{l}\text { Designing the frameworks for } \\
\text { negotiations data and knowledge } \\
\text { bases and inventing effective } \\
\text { procedures to process and supply } \\
\text { desired information. }\end{array}$ & $\begin{array}{ll}\text { 1. } & \text { Methods of modeling } \\
\text { 2. } & \text { Methods of knowledge bases building } \\
\text { 3. } & \text { Heuristic methods } \\
\text { 4. } & \text { Experts' methods } \\
\text { 5. } & \text { Knowledge and data bases } \\
\text { 6. } & \text { Negotiation Support Systems } \\
\end{array}$ \\
\hline Social & $\begin{array}{l}\text { Suggesting conciliatory patterns of } \\
\text { individual and group behaviors and } \\
\text { attitudes, stimulating the search for } \\
\text { integrative solutions and allowing } \\
\text { establishing positive relationships } \\
\text { between the parties. }\end{array}$ & $\begin{array}{l}\text { 1. Methods of team building and management } \\
\text { 2. Techniques of modeling group structure and } \\
\text { behavior } \\
\text { 3. Methods of modeling intra-group relations - } \\
\text { sociographs, network analysis, etc. } \\
\text { 4. Psychological methods - self-assessment test, } \\
\text { of skills, abilities, and personal features, } \\
\text { transactional analysis, interviews, } \\
\text { questionnaires, etc. } \\
\text { 5. Sociological methods - action research, } \\
\text { group role models and analysis, etc. } \\
\text { 6. Heuristic methods } \\
\text { 7. Multidimensional analysis } \\
\text { 8. Soft systems thinking model }\end{array}$ \\
\hline Procedural & $\begin{array}{l}\text { Formulating useful rules for } \\
\text { structuring negotiation processes in } \\
\text { the form of rational procedures with } \\
\text { acceptable level of stringency } \\
\text { (formalization vs. flexibility) as well } \\
\text { as establishing standards of } \\
\text { performing those processes. }\end{array}$ & $\begin{array}{l}\text { 1. Methods of modeling (quantitative and } \\
\text { qualitative) } \\
\text { 2. Techniques of group structuring } \\
\text { 3. Methods of process performance standards } \\
\text { establishing } \\
\text { 4. Heuristic methods } \\
\text { 5. Experts' methods } \\
\text { 6. Multidimensional analysis } \\
\text { 7. Process diagrams and maps } \\
\text { 8. Soft systems thinking model }\end{array}$ \\
\hline Strategic & $\begin{array}{l}\text { Elaborating } \text { effective } \text { collective } \\
\text { decision making procedures, } \\
\text { techniques and rules as well as } \\
\text { suggesting optional negotiation } \\
\text { strategies, rules for selecting them } \\
\text { and adjusting to particular } \\
\text { negotiations situations, emphasizing } \\
\text { the role of coalitions. }\end{array}$ & $\begin{array}{l}\text { 1. Methods of modeling (quantitative and } \\
\text { qualitative) } \\
\text { 2. Methods of collective decision-making } \\
\text { 3. Heuristic methods } \\
\text { 4. Experts' methods } \\
\text { 5. Rational models of decision making } \\
\text { 6. Models of coalitions building } \\
\text { 7. Models of negotiations strategies } \\
\text { 8. Methods of simulation }\end{array}$ \\
\hline
\end{tabular}

Apart from the tools listed in Table 2 and Table 3 it is necessary to include four classic decision making concepts that allow solving problems in negotiations (Raiffa et al. 2002):

- decision analysis (prescriptive approach): enables to create and analyze alternative solutions, independently from the assumptions and expectations of the other party; comprises a number of models and detailed techniques, mostly quantitative, such as decision trees and tables (matrixes); 
- behavioral decision making (descriptive, qualitative approach): explains negotiators' behaviors, creates rational models for decision making as well as points out principles and bounds of rationality and particular decision making tools (criteria, rules, techniques);

- game theory (normative approach): quantitative models dealing with the matter of how one should make the decisions, which are considered separately by negotiators, but simultaneously connected with each other; explains the mechanisms and circumstances of conflicts of interests and seeks for their optimal resolutions;

- $\quad$ negotiation analysis (prescriptive approach): clarifies how both parties make decisions jointly (in cooperation), which allows them to create and select solutions that satisfy their needs and expectations; by the application of either models using utility theory or the other models (both quantitative and qualitative).

Summing up, it can be stated that the concept presented above may play a vital role in both theory building as well as improving practice of multiparty negotiation from the perspective of management sciences. The future research area could be empirical research focused on the verification of the proposed conceptual framework of method selection for problem-solving of multiparty negotiations.

\section{Funding}

This work was partly supported by the National Science Centre, Poland, Grant number 2014/13/B/HS4/03452.

\section{References}

Agndal, H., Åge, L. J., \& Eklinder Frick, J. (2017). Two decades of business negotiation research: an overview and suggestions for future studies. Journal of Business \& Industrial Marketing, 32(4), 487-504, https://doi.org/10.1108/JBIM-112015-0233

Alder, N. J., Graham, J.L., \& Gehrke, T.S. (1988). Business negotiations in Canada, Mexico, and the United states. International Executive, 30(1), 13-15.

Banathy, B. H. (1996). Designing social systems in a changing world. New York: Plenum Press. 
Caputo, A. (2013). The third who joins a negotiation: A systematic review of the literature. International Journal of Business and Globalisation, 10(3), 256-277.

Caputo, A. (2019). Multilateral Negotiations. In Strategic Corporate Negotiations (pp. 29-46). Palgrave Pivot, Cham.

Cowan, D. A. (1991). The effect of decision-making styles and contextual experience on executives' descriptions of organizational problem formulation. Journal of Management Studies, 28(5), 463-483.

Crump, L. \& Glendon, A. I. (2003). Towards a paradigm of multiparty negotiation. International Negotiation, 8(2), 197-234.

Crump, L. (2003). Multiparty negotiation and the management of complexity. International Negotiation, 8(1), 1-5.

Crump, L. (2015). Analyzing complex negotiations. Negotiation Journal, 31(2), 131-153.

Curhan, J. R., Elfenbein, H. A., \& Eisenkraft, N. (2010). The objective value of subjective value: a multi-round negotiation study. Journal Applied Social Psychology, 40(3), 690-709.

Dupont, C. (1994). Coalition Theory. Using Power to Build Cooperation, In W.I. Zartman (ed.), International Multilateral Negotiation. Approaches to the Management of Complexity, San Francisco: Jossey-Bass.

Esqueda, P. (2012). Developing a global logistic hub: A teaching case in multiparty collaboration and negotiation. International Journal of Procurement Management, 5(4), 502-516.

Franco, L. A. (2008). Facilitating collaboration with problem structuring methods: A case study of an inter-organisational construction partnership. Group Decision and Negotiation, 17(4), 267-286.

Gift, R. G. \& Kinney, C. F. (1996). Management method selection implications and future directions, In R. G. Gift, C. F. Kinney (eds.), Today’s Management Methods: A Guide for the Health Care Executive, San Francisco: Jossey-Bass.

Grabowska, A. \& Kozina, A. (2016). Interactive approach to negotiating styles dependent on personality traits. Journal of Management and Business Administration Central Europe, 24(1), 2-16. 
Greenhalgh, L. (2001). Managing Strategic Relationships. New York: The Free Press.

Greenhalgh, L., Neslin, S., \& Gilkey, R. (1985). The effects of negotiator preferences, situational power, and negotiator personality on outcomes of business negotiations. Academy of Management Journal, 28(1), 9-33.

Hagemeyer, C., Gershenson, J. K. \& Johnson, D. M. (2006). Classification and application of problem solving quality tools. A manufacturing case study. The TQM Magazine, 18(5), 455-483.

Heiskanen, P. (1999). Decentralized method for computing pareto solutions in multi-party negotiations. European Journal of Operational Research, 117, 578-590.

Holland, S., \& Dawson, R. (2011). Classification and selection of tools for quality knowledge management. Software Quality Journal, 19, 393-409.

Holt, D. H. (1987). Management: Principles and Practices, Prentice Hall.

Inkpen, A. C., \& Ross, J. (2001). Why do some strategic alliances persist beyond their useful life? California Management Review, 44, 132-148.

Jang, D., Elfenbein, H. A., \& Bottom, W. P. (2018). More than a phase: form and features of a general theory of negotiation. Academy of Management Annals, 12(1), 318-356. https://doi.org/10.5465/annals.2016.0053

Jun, T., Z. Morris, T. Eldabi, P. Harper, A. Naseer, B. Patel, \& Clarkson, J.P. (2011). Development of modelling method selection tool for health services management: from problem structuring methods to modelling and simulation methods. BMC Health Services Research, 11(108), 1-11.

Kamiński, J. (2003). Negocjowanie. Techniki rozwiązywania konfliktów. Warszawa: Poltext.

Kaufman, S., Ozawa, C. \& Shmueli, D. (2018). Negotiations in the public sector: Applying negotiation theory to multiparty conflicts. Négociations, 29(1), 59-73.

Kern, M. C., Brett, J. M., Weingart, L. R., Eck, C. S. (2020). The "fixed" pie perception and strategy in dyadic versus multiparty negotiations. Organizational Behavior and Human Decision Processes, 157, 143-158. 
Klenk, A., Beck-Greinwald, A., Angst, H., \& Carle, G. (2012). Iterative multi-party agreement negotiation for establishing collaborations. Service Oriented Computing and Applications, 6(4), 321-335.

Kozina, A. (2012). Multiparty Negotiations - Research Problems Formulation. In A. Nalepka and A. Ujwary-Gil (Eds.), Business and Non-profit Organizations Facing Increased Competition and Growing Customers' Demands, Nowy Sącz: Wyższa Szkoła Biznesu-National-Louis University.

Kozina, A. (2014). Evaluation of bargaining power. Journal of Management and Business Administration. Central Europe, 22(3), 72-84.

Kramer, R. M. (1991). The more the merrier? Social psychological aspects of multiparty negotiations in organizations. In Bies R. J., Lewicki R. J., \& Sheppard B. H. (Eds.), Research on Negotiation in Organizations, Vol. 2, Greenwich, Conn.

Lee, J., Zhang, H., \& Gray, B. (2019). Beyond the dyad: studying the complex dynamics of multiparty negotiations. Academy of Management Annual Meeting Proceedings, https://doi.org/10.5465/AMBPP.2019.11738symposium

Lee, K. C., \& Kwon, S. J. (2006). The use of cognitive maps and case-based reasoning for B2B negotiation. Journal of Management Information Systems, 22(4), 337-376.

Lewicki, R.J., Saunders, D.M., \& Barry, B. (2010). Essentials of Negotiation, 5th edition, New York: McGraw-Hill.

Lisiński, M. (2013). Structural analysis of the management science methodology. Business, Management and Education, 11(1), 109-136.

Maier, N. R. F., \& Hoffman, L. R. (1964). Types of problems confronting managers. Personnel Psychology, 17, 261-269.

Mingers, J. \& Gill, A. (1997). Multimethodology: Theory and Practice of Combining Management Science Methodologies, New York: Wiley.

Nadler, G. (1967). Work Systems Design: The IDEALS Concept, Homewood: Irwin.

Nadler, G. (1981). Planning and Design Approach. New York: John Wiley \& Sons. 
Nadler, G. (1983). Human purposeful activities for classifying management problems. Omega, 11, 15-26.

Olekalns, M., \& Smith, P. (2009). Mutually Dependent: Power, trust, affect and the use of deception in negotiation. Journal of Business Ethics, 85, 347-365.

Potocan, V., Z. Nedelko, \& Mulej, M. (2012). Influence of organizational factors on management tools usage in Slovenian organizations. Engineering Economics, 23(3), 291-300.

Raiffa, H., Richardson J., \& Metcalfe, D. (2002). Negotiation Analysis. The Science and Art of Collaborative Decision Making. Cambridge: The Belknap Press of Harvard University Press.

Roth, W. (1994). The Evolution of Management Theory: Past, Present, Future, CRC Press.

Sagi, E., \& Diermeier, D. (2017). Language use and coalition formation in multiparty negotiations. Cognitive Science, 41(1), 259-271.

Sarabando, P., Dias, L. C. \& Vetschera, R. (2013). Mediation with incomplete information: approaches to suggest potential agreements. Group Decision and Negotiation, 22(3), 561-597.

Scandura, T. A., \& Williams, E. A. (2000). Research methodology in management: current practices, trends, and implications for future research. Academy of Management Journal, 43(6), 1248-1264.

Simon, H. A. (1973). The structure of ill-structured problems. Artificial Intelligence, 4, 181-201.

Smith, G. F. (1988). Towards a heuristic theory of problem structuring. Management Science, 34(12), 1489-1506.

Susskind, L. E. \& Crump, L. (2008). Multiparty Negotiation. London: Sage Publications.

Szarucki, M. (2010). Developing classification criteria for organizational problems. Business and Management 2010. Selected Papers, Vol. II, VGTU Publishing House "Technika”, Vilnius, 1100-1106. 
Szarucki, M. (2013). Model of method selection for managerial problem solving in an organization. Business, Management and Education, 11(1), 168-187.

Szarucki, M. (2015). Evolution of managerial problems from the perspective of management science. Business: Theory and Practice, 16(4), 362-372.

Thompson, L. L. (2016). The Mind and Heart of The Negotiator. 6th edition, Upper Saddle River: Prentice Hall.

Tinsley, C., Curhan, J. R., \& Kwok, R. S. (1999). Adopting a dual lens approach for overcoming the dilemma of difference in international business negotiations. International Negotiation, 4(4), 1-18.

Toni, A. D., Caputo M., \& Vinelli, A. (1988). Production management techniques: push-pull classification and application conditions. International Journal of Operations \& Production Management, 8(2), 35-51.

Van Beest, I., Van Kleef, G. A., \& Van Dijk, E. (2008). Get angry, get out: The interpersonal effects of anger communication in multiparty negotiation. Journal of Experimental Social Psychology, 44(4), 993-1002.

Walsh, J. P. (1988). Selectivity and selective perception: An investigation of managers' belief structures and information processing. Academy of Management Journal, 31, 873-896.

Watkins, M. (2002). Breakthrough Business Negotiation: A Toolbox for Managers. New York: John Wiley \& Sons.

Wren, D. A. \& Bedeian, A. G. (2009). The Evolution of Management Thought. 6th edition, Hoboken: John Wiley and Sons.

Zartman, W. I. (1994). Two's company and more's a crowd. The complexity of multilateral negotiation. In Zartman W. I. (ed.), International Multilateral Negotiation. Approaches to the Management of Complexity, San Francisco: JosseyBass.

Zhou, J., Zhang, Z. R., \& Xie, T. (2014). Making collaborators happy: The outcome priming effect in integrative negotiation. Public Personnel Management, 43(3), 290-300. 